Article

\title{
Growth Hormone Promotes Motor Function after Experimental Stroke and Enhances Recovery-Promoting Mechanisms within the Peri-Infarct Area
}

\author{
Sonia Sanchez-Bezanilla ${ }^{1,2}\left(\mathbb{D}\right.$, N. David Åberg ${ }^{3,4}$, Patricia Crock ${ }^{2,5}$, Frederick R. Walker ${ }^{1,2,6,7}$, \\ Michael Nilsson ${ }^{1,2,6,7,8}$, Jörgen Isgaard ${ }^{1,3,4, *,+}$ and Lin Kooi Ong 1,2,6,9,*,+(D) \\ 1 School of Biomedical Sciences and Pharmacy and the Priority Research Centre for Stroke and Brain Injury, \\ the University of Newcastle, University Dr, Callaghan, NSW 2308, Australia; \\ sonia.sanchezbezanilla@uon.edu.au (S.S.-B.); rohan.walker@newcastle.edu.au (F.R.W.); \\ michael.nilsson@newcastle.edu.au (M.N.) \\ 2 Brain and Mental Health, Hunter Medical Research Institute, Lot 1, Kookaburra Cct, New Lambton Heights, \\ NSW 2305, Australia; patricia.crock@newcastle.edu.au \\ 3 Department of Internal Medicine, University of Gothenburg, 40530 Gothenburg, Sweden; \\ david.aberg@medic.gu.se \\ 4 Department of Internal Medicine, Region Västra Götaland, Sahlgrenska University Hospital, Blå stråket 5, \\ 41345 Gothenburg, Sweden \\ 5 Department of Paediatric Endocrinology and Diabetes, John Hunter Children's Hospital, Kookaburra Cct, \\ New Lambton Heights, NSW 2305, Australia \\ 6 NHMRC Centre of Research Excellence Stroke Rehabilitation and Brain Recovery, 245 Burgundy Street, \\ Heidelberg, VIC 3084, Australia \\ 7 Centre for Rehab Innovations, Lot 1, Kookaburra Cct, New Lambton Heights, NSW 2305, Australia \\ 8 LKC School of Medicine, Nanyang Technological University, 50 Nanyang Ave, Singapore 639798, Singapore \\ 9 School of Pharmacy, Monash University Malaysia, Bandar Sunway, Subang Jaya 47500, Selangor, Malaysia \\ * Correspondence: jorgen.isgaard@medic.gu.se (J.I.); ong.linkooi@monash.edu (L.K.O.) \\ + These authors contributed equally to this work.
}

Received: 20 December 2019; Accepted: 15 January 2020; Published: 17 January 2020

check for updates

\begin{abstract}
Motor impairment is the most common and widely recognised clinical outcome after stroke. Current clinical practice in stroke rehabilitation focuses mainly on physical therapy, with no pharmacological intervention approved to facilitate functional recovery. Several studies have documented positive effects of growth hormone $(\mathrm{GH})$ on cognitive function after stroke, but surprisingly, the effects on motor function remain unclear. In this study, photothrombotic occlusion targeting the motor and sensory cortex was induced in adult male mice. Two days post-stroke, mice were administered with recombinant human GH or saline, continuing for 28 days, followed by evaluation of motor function. Three days after initiation of the treatment, bromodeoxyuridine was administered for subsequent assessment of cell proliferation. Known neurorestorative processes within the peri-infarct area were evaluated by histological and biochemical analyses at 30 days post-stroke. This study demonstrated that GH treatment improves motor function after stroke by $50 \%-60 \%$, as assessed using the cylinder and grid walk tests. Furthermore, the observed functional improvements occurred in parallel with a reduction in brain tissue loss, as well as increased cell proliferation, neurogenesis, increased synaptic plasticity and angiogenesis within the peri-infarct area. These findings provide new evidence about the potential therapeutic effects of GH in stroke recovery.
\end{abstract}

Keywords: Ischemic stroke; growth hormone; motor recovery; neurogenesis; neuronal plasticity; vascular remodelling 


\section{Introduction}

Globally, stroke is a leading cause of disability [1]. The most common and widely recognised neurological impairments caused by stroke are deficits in motor function [2]. Therefore, motor-based rehabilitation techniques have been developed to promote the recovery of motor impairments in stroke patients [3-7]. Current clinical practice for impaired sensorimotor functions are mainly based on physical therapy starting within $48 \mathrm{~h}$ of stroke onset, which can last for as long as months and years after the stroke $[4,8]$. Rehabilitation after stroke is often a long and slow process, and therefore, the development of new effective therapeutic strategies that can enhance the recovery of brain function and improve functional outcomes are highly desirable. An innovative solution may be the use of a pharmacological strategy to promote a pro-restorative environment within the brain. One promising strategy in this regard is growth hormone (GH).

The therapeutic potential of GH on brain repair after brain injury or stroke has been considered in both human [9-18] and preclinical [19-24] studies. GH, a peptide hormone released from the anterior pituitary gland, plays an important role in brain growth, development and function [11]. Critically, prior work has documented the widespread expression of $\mathrm{GH}$ and growth hormone receptor (GHR) in the rat brain [25], and the ability of GH to stimulate the genesis of neuronal stem cells [26] and endothelial cells, as well as to promote synaptogenesis [27]. It is well known that any injury to the adult brain generates an adaptive brain repair response, which includes the proliferation of new cells and differentiation into different populations [28-31]. Previous experimental studies have shown that ischemic injury induces proliferation of newly born neurons in the subventricular zone, migration of these immature neurons and localization within the peri-infarct region [31-36]. However, this self-repair mechanism operates only acutely after stroke and is insufficient to promote long-term recovery. Interestingly, several experimental studies have shown that GH can promote these neurorestorative or plasticity-promoting processes beyond what occurs with spontaneous recovery after brain injury or stroke, and this increased neurorestoration is closely linked with improvement in functional outcomes $[9,11,15,18,37,38]$. Despite the fact that the positive effects of GH in the adult brain have been extensively studied, it is still not clear whether GH could promote motor function after stroke.

In previous studies, we assessed the pro-cognitive effects of peripherally administered GH after experimental stroke and the possible underlying mechanisms leading to such effects. We found that GH treatment promotes cognitive recovery after stroke, however sensorimotor effects were not evaluated. In addition, we found an increased expression of neurotrophic factors, markers of synaptogenesis and myelination, and the formation of new blood vessels [39]. However, there is still a large gap in our understanding of whether GH treatment could also enhance motor function after stroke, and whether this is associated with neurorestorative processes within the peri-infarct regions.

In this study, we aimed to evaluate whether GH treatment could promote motor function after experimental stroke. Our primary hypothesis was that mice who received stroke that were then treated with recombinant human growth hormone (rhGH) for 28 days, starting at $48 \mathrm{~h}$ post-stroke, would improve performance in motor tasks relative to non-rhGH-treated stroke mice. Our secondary hypothesis was that the rhGH-treated stroke mice would show an enhancement in known neurorestorative processes within the peri-infarct region. We assessed cellular and molecular changes using comprehensive and cross-validated approaches, including bromodeoxyuridine (BrdU) tagging, co-immunolabelling and western blotting analyses.

\section{Results}

\subsection{GH Treatment Improves Motor Function}

We treated the mice with either saline $(n=10)$ or rhGH $(n=10)$ using a mini-osmotic pump, starting at $48 \mathrm{~h}$ post-stroke for 28 days. Mice were assessed for motor deficits one day before stroke (pre-stroke), one day after stroke (post-stroke) and at 29 days post-stroke (post-treatment) (Figure 1A). 
We used the cylinder task to evaluate locomotor asymmetry. This task evaluates the forelimb preference that mice utilise for upright postural support when rearing up on the cylinder wall. Data on the asymmetry scores indicated that there were no significant differences in forelimb preference prior to stroke. One day after stroke, all mice showed a significantly stronger preference for using their ipsilateral (unaffected) forelimb. At 29 days post-stroke, we found a significant motor improvement $(50.32 \%, p=0.0123)$ in rhGH-treated stroke mice compared with saline-treated mice (Figure 2A). Motor function was also assessed using the grid walk task. This task evaluates the ability of mice to effectively place their paws on an elevated grid during locomotion. As expected, there was no difference in the number of foot faults before stroke. One day after stroke, the number of foot faults on the contralateral (affected side) was significantly higher in all stroke mice. At 29 days post-stroke, there was a significant effect of rhGH treatment on motor function recovery $(64.27 \%, p<0.0001$; Figure 2B).

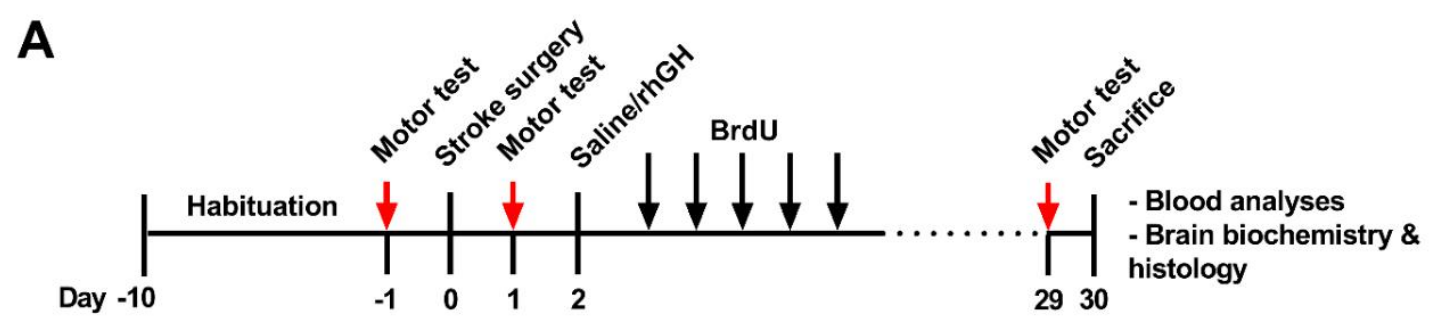

B

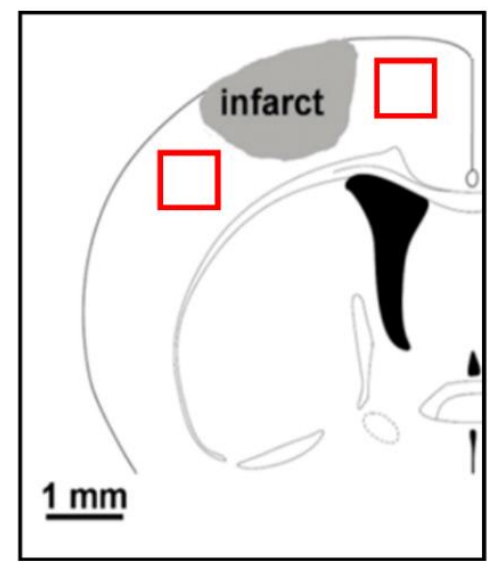

Figure 1. (A) Experimental timeline. Photothrombotic stroke was induced in all mice. Two days post-stroke, mice were randomly treated with either saline or recombinant human growth hormone (rhGH) via mini-osmotic pumps for 28 days. At day 3, mice were injected with bromodeoxyuridine (BrdU) for 5 consecutive days. Mice were assessed by motor tests at one day before stroke (pre-stroke), one day after stroke (post-stroke) and 29 days post-stroke (post-treatment). (B) Diagram illustrating the site of photothrombotic stroke induction (grey area) at Bregma $0.0 \mathrm{~mm}$. Red squares represent the area of the peri-infarct region selected for immunofluorescence analyses. The peri-infarct territory, which is found in the $2 \mathrm{~mm}$ around the infarct core, was dissected for protein analysis. Bar $=1 \mathrm{~mm}$. 
A
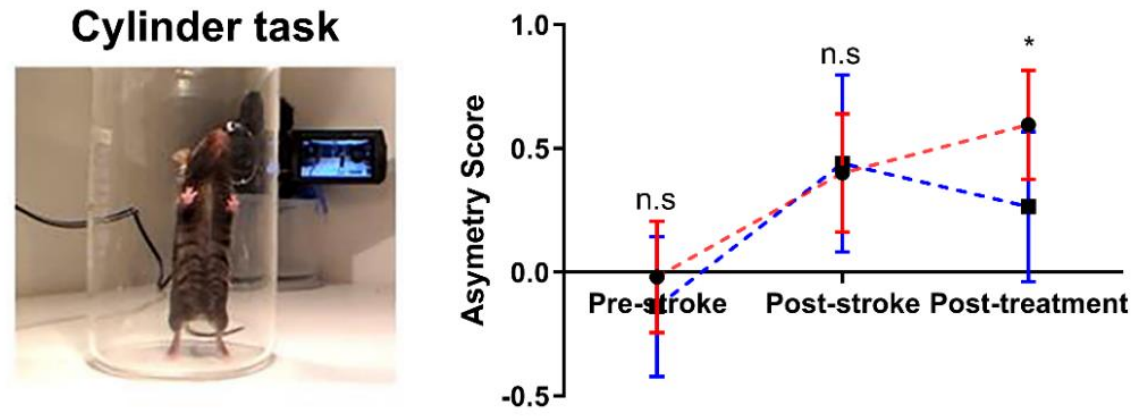

B
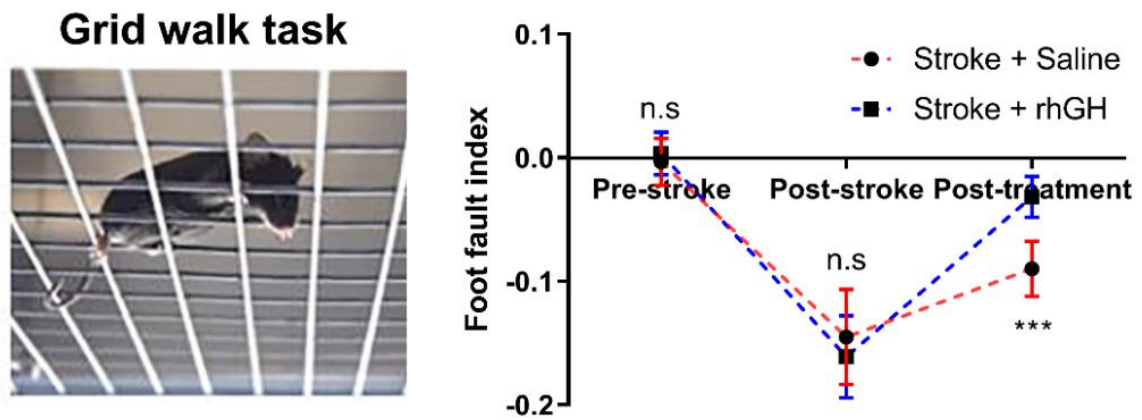

Figure 2. The effects of recombinant human growth factor (rhGH) treatment post-stroke on motor function. (A) Asymmetry scores were evaluated by the cylinder test, which shows that mice that received rhGH treatment significantly improve motor function. (B) A foot fault index was evaluated by the grid walk test, which also shows an improvement in motor function after rhGH treatment. In all panels, red colour designates saline treatment and blue designates rhGH treatment. Mean \pm standard deviation (SD). n.s = not significant. ${ }^{*} p<0.05$ and ${ }^{* *} p<0.001$.

\subsection{GH Treatment Increases Plasma IGF-1 Levels}

rhGH treatment administered post-stroke significantly increased insulin-like growth factor 1 (IGF-1) (Saline treatment $289.9 \pm 36.14$ versus rhGH treatment $433.5 \pm 44.2 \mathrm{ng} / \mathrm{mL}, 49.51 \%, p<0.0001$ ) and IGFBP-3 (Saline treatment $254.3 \pm 50.06$ versus rhGH treatment $293.7 \pm 26.1 \mathrm{ng} / \mathrm{mL}, 15.49 \%, p=0.0405$ ) levels in plasma, assessed at time of sacrifice. These results have confirmed that commercially available rhGH has significant effects on mouse physiology when delivered subcutaneously via a mini-osmotic pump. Further, we assessed the association between plasma IGF-1 and motor performance. A Pearson correlation analysis showed a significant positive correlation between plasma IGF-1 levels and cylinder task performance post $\mathrm{rhGH}$ treatment $\left(\mathrm{r}=-0.6789 ; p_{(\mathrm{Y}=-0.002513 \mathrm{X}+1.339)}=0.0010\right)$ (Supplementary Figure S3A). There was also a significant correlation between plasma IGF-1 levels and the grid walk task performance post rhGH treatment $\left(\mathrm{r}=0.8879 ; p_{(\mathrm{Y}=0.0003785 \mathrm{X}-0.1977)}<0.0001\right)$ (Supplementary Figure S3B).

\subsection{GH Treatment Reduces Tissue Loss}

Using Cresyl Violet staining, we estimated the tissue loss at 0.0 and $-2.0 \mathrm{~mm}$ from Bregma. We found a significant decrease in tissue loss at Bregma $0.0 \mathrm{~mm}$ at 30 days post stroke in mice treated with rhGH $(29.89 \%, p=0.0088$; Figure 3). 

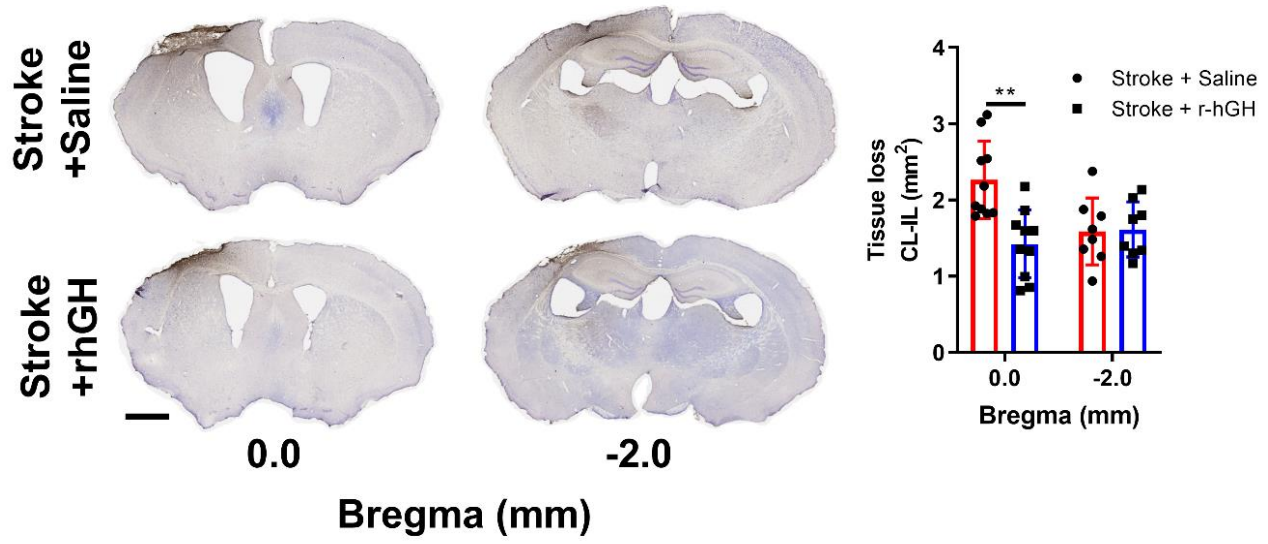

Figure 3. Cresyl violet staining of brain sections from Bregma 0.0 and $-2.0 \mathrm{~mm}$. Tissue loss was calculated as contralateral (CL) hemisphere area - ipsilateral (IL) hemisphere area $\left(\mathrm{mm}^{2}\right) .{ }^{* *} p<0.01$. Bar $=1 \mathrm{~mm}$.

\subsection{GH Treatment Promotes Cell Proliferation and Neurogenesis within the Peri-Infarct Region}

We assessed several selected neurorestorative effects of rhGH after stroke using an immunolabelling approach. Firstly, we performed BrdU and neuronal nuclei (NeuN) co-labelling (Figure 4A). BrdU is an analogue of the nucleoside thymidine, which can be incorporated into replicating DNA and therefore can be used to identify proliferating cells [40]. In the peri-infarct region, we found a significant increase in the number of BrdU-positive cells in stroke mice treated with rhGH compared with saline-treated mice $(109.67 \%, p=0.0035$; Figure 4B). We also observed an increase in the number of NeuN-positive neurons $(9.10 \%, p=0.0256)$ (Figure $4 \mathrm{C})$. To assess whether these proliferating cells have differentiated into neurons, we analysed co-localisation of BrdU and NeuN labelling. rhGH treatment post-stroke significantly increased the number of BrdU-NeuN-positive cells (139.44\%, $p=0.0073$; Figure 4D).

\section{A}
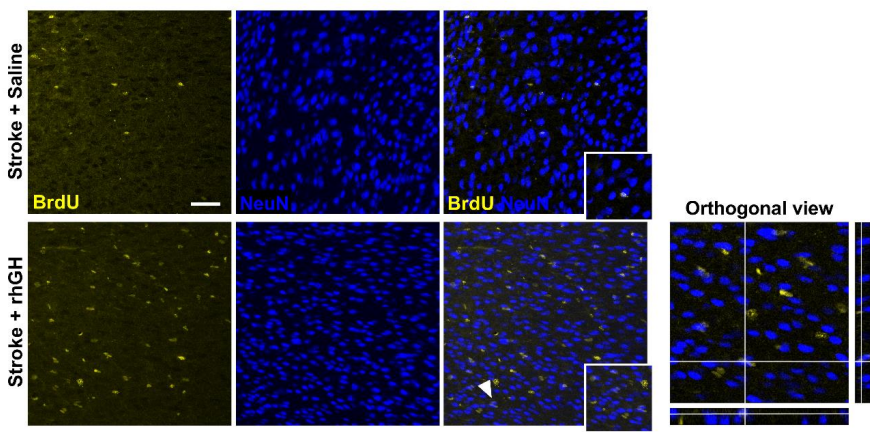

B

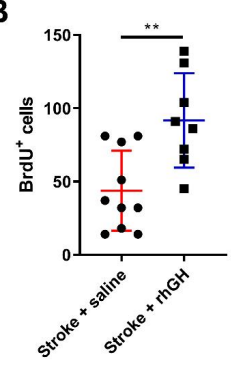

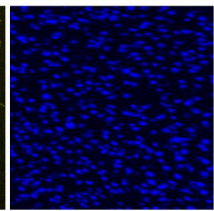

C

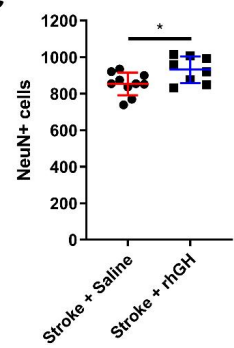

D

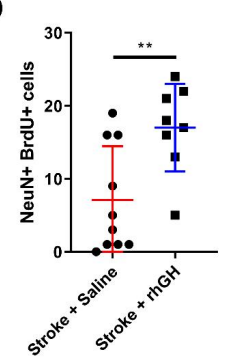

Figure 4. rhGH treatment promotes cell proliferation and neurogenesis in the peri-infarct region. (A) Representative immunofluorescence images, which are co-labelled with BrdU (yellow) and neuronal nuclei (NeuN, blue), with orthogonal view also presented (far right). The white arrowhead shows a co-labelled cell visualised in orthogonal view. (Scale bar $=50 \mu \mathrm{m}$ ). rhGH treatment post-stroke significantly increased the number of (B) BrdU-positive cells, (C) NeuN-positive cells, and (D) BrdU-NeuN-positive cells. Mean \pm SD. ${ }^{*} p<0.05$ and ${ }^{* *} p<0.01$. 
Next, we analysed the levels of doublecortin (DCX), a marker of immature neurons [41]. DCX is a microtubule-associated protein, which is necessary in the proliferation of progenitor cells during neurogenesis [42,43]. Optical density of DCX immunofluorescence images within the peri-infarct region were quantitatively assessed using a threshold analysis protocol. This immunofluorescence data revealed a significant increase in material thresholded for DCX $(201.97 \%, p=0.0115$, at pixel intensity 225; Figure 5A) in stroke mice treated with rhGH compared with saline treatment. We further confirmed this histology data using a western blot protocol. The protein homogenates from the peri-infarct region of stroke + saline and stroke + rhGH cohorts were analysed along with a sham + saline cohort. We found a significant increase in DCX levels (0.44-fold, $p=0.0010$; Figure 5C) after rhGH treatment.

A

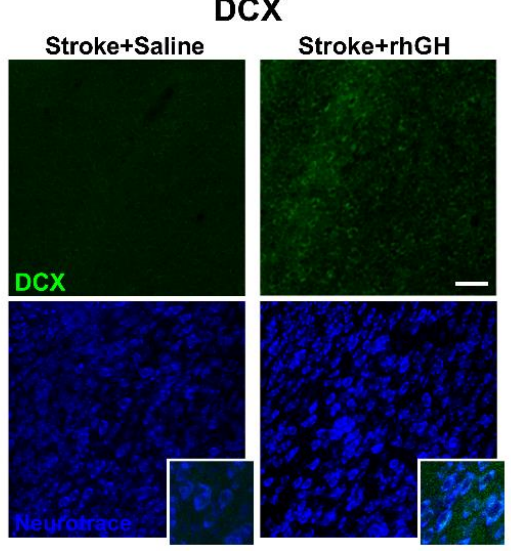

B

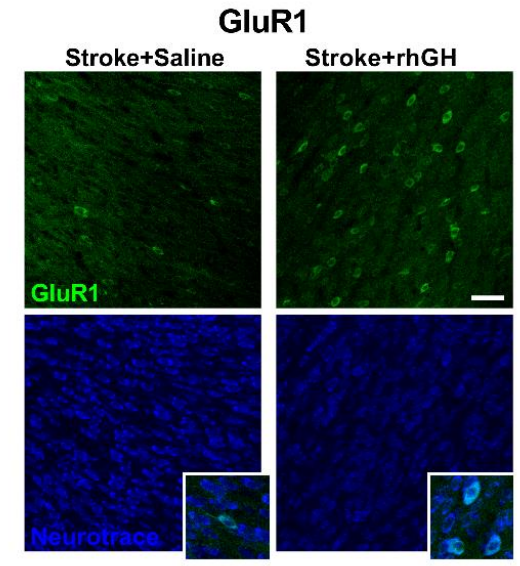

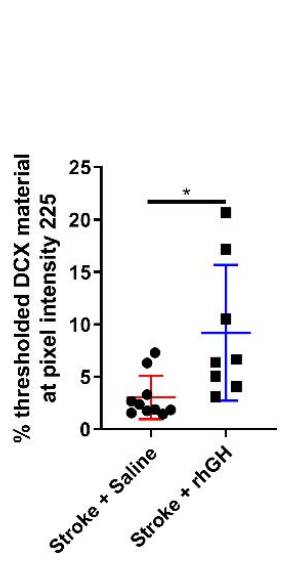
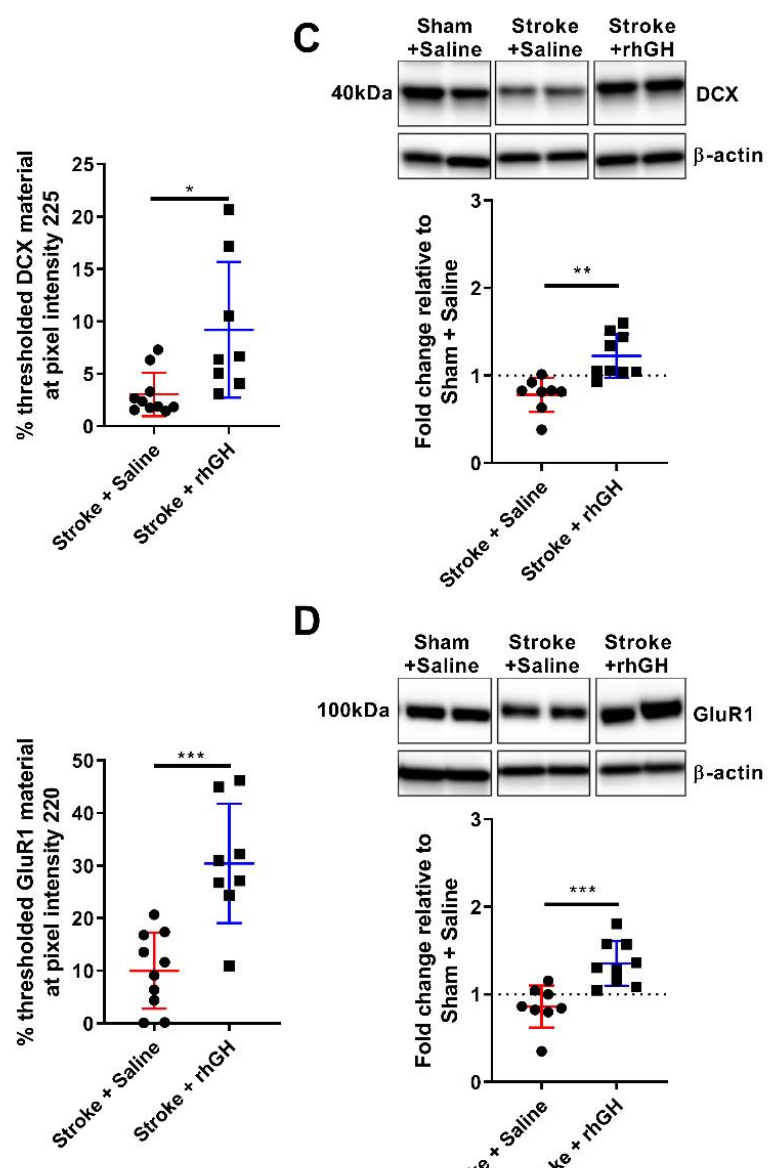
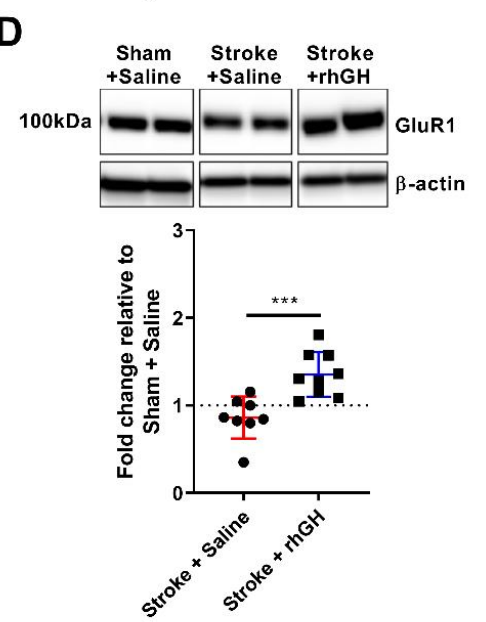

Figure 5. Increased expression of both Doublecortin (DCX) and $\alpha$-amino-3-hydroxy-5-methyl4-isoxazolepropionic acid receptor 1 (GluR1) in the peri-infarct region after rhGH treatment. (A) Representative confocal images of peri-infarct areas co-labelled with DCX (green) and Neurotrace (blue) and high magnification (Scale bar $=50 \mu \mathrm{m}$ ). Quantification of material threshold at the pixel intensity 225 shows an increase in DCX-positive structures after rhGH treatment. (B) Representative confocal images of peri-infarct areas co-labelled with GluR1 (green) and Neurotrace (blue), and high magnification (Scale bar $=50 \mu \mathrm{m}$ ). Quantification of material threshold at the pixel intensity 220 shows increased GluR1-positive structures after rhGH treatment. (C) Representative western blot and quantification using anti-DCX antibody within the peri-infarct region. Quantification revealed increased expression of DCX in rhGH-treated mice. (D) Representative western blot and quantification using anti-GluR1 antibody within the peri-infarct region. Quantification revealed increased expression of GluR1 in rhGH-treated mice. Mean \pm SD. ${ }^{*} p<0.05,{ }^{* *} p<0.01$ and ${ }^{* * *} p<0.001$. 


\subsection{GH Treatment Promotes Expression of GluR1 within the Peri-Infarct Region}

We also assessed the levels of $\alpha$-amino-3-hydroxy-5-methyl-4-isoxazolepropionic acid receptor 1 (GluR1). GluR1 is a receptor implicated in synapse formation, stabilisation, and plasticity [44]. The immunofluorescence data revealed a significant increase in material threshold for GluR1 (203.54\%, $p=0.0003$, at pixel intensity 220; Figure 5B) in stroke mice treated with rhGH compared with saline-treated mice. The western blot data also shows a significant increase in GluR1 (0.49-fold, $p=0.001$; Figure 5D) levels after rhGH treatment.

\subsection{GH Treatment Promotes Angiogenesis within the Peri-Infarct Region}

We next analysed the brain vasculature after rhGH treatment (Figure 6A). To assess vascular density, we used Lectin as a blood vessel staining and we performed a digital reconstruction of vessels for analysis of the immunofluorescence images. We found a significant increase in the percentage area covered by Lectin within the peri-infarct region in stroke mice treated with rhGH compared with saline treatment $(18.20 \%, p=0.0129$; Figure 6B).

A
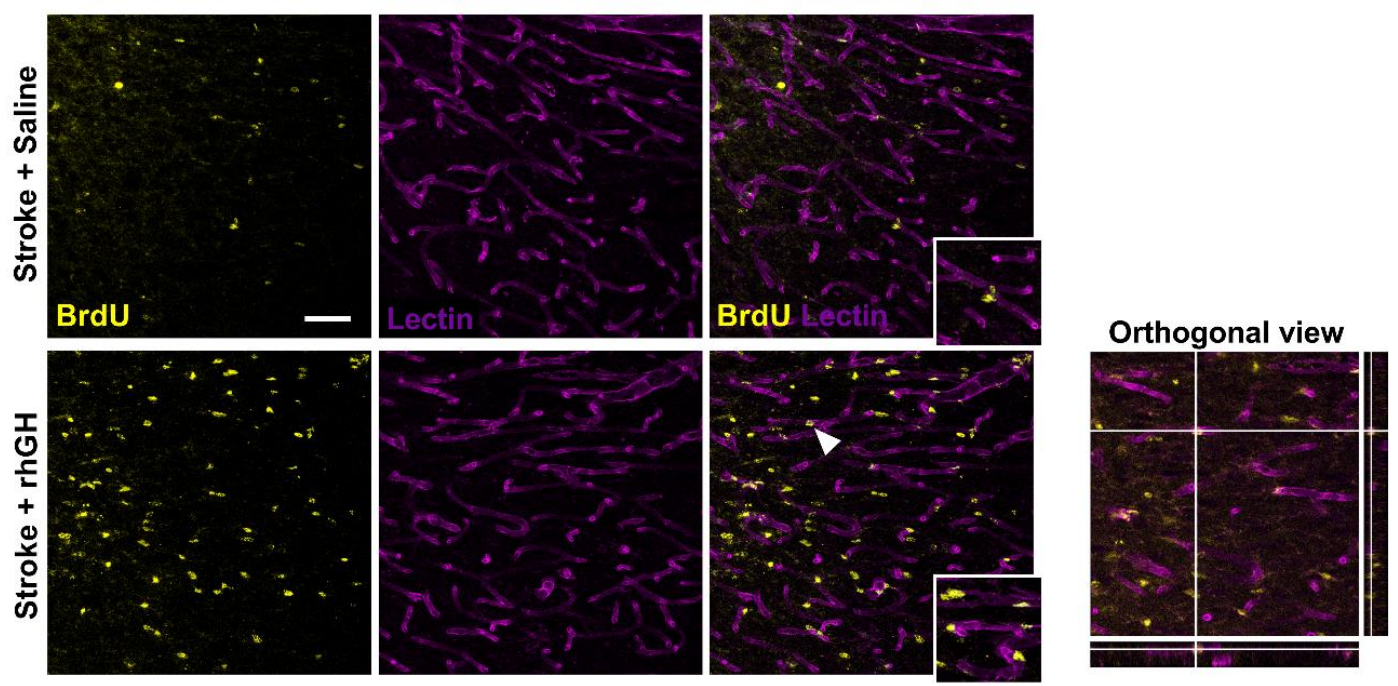

B
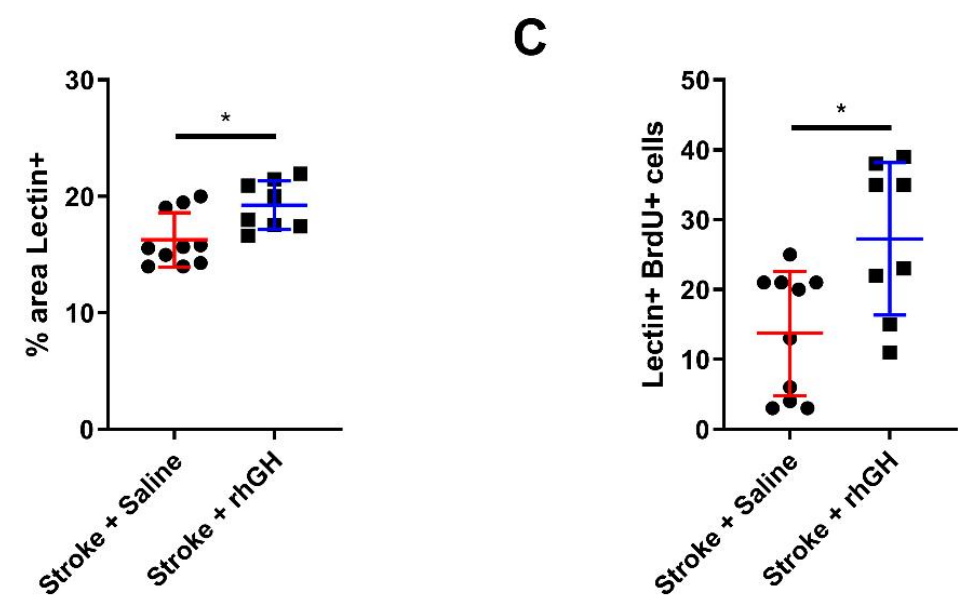

Figure 6. rhGH treatment promotes angiogenesis in the peri-infarct region post-stroke. (A) Representative immunofluorescence images of cells co-labelled with BrdU (yellow) and Lectin (purple) and orthogonal view (far right). The white arrowhead shows a cell visualised in orthogonal view. (Scale bar $=50 \mu \mathrm{m}$ ). rhGH treatment post-stroke significantly increased the \% of area that was positive for (B) Lectin and (C) the number of BrdU-Lectin-positive cells. Mean \pm SD. ${ }^{*} p<0.05$. 
To assess whether the BrdU-positive cells have differentiated into endothelial cells, we performed co-labelling analyses of BrdU with Lectin. We found that rhGH treatment post-stroke significantly increased the number BrdU-Lectin-positive cells (98.91\%, $p=0.0103$; Figure 6C).

\section{Discussion}

The main finding of the present study is that GH treatment improves motor function after experimental stroke. Specifically, GH treatment for 28 days starting $48 \mathrm{~h}$ post photothrombotic stroke significantly improved motor function, when compared with non-GH-treated stroke mice. Motor function was assessed using two different tasks, and in both tasks, GH treatment significantly improved motor deficits. GH treatment reduced the preference for spontaneous use of ipsilateral forelimbs during the cylinder task and decreased the number of foot-faults on the grid walk task. Secondly, we studied selected neurorestorative processes, which have been previously linked to motor improvement. We observed an increase in proliferation of progenitor cells, neurogenesis, increased synaptic plasticity and angiogenesis within the peri-infarct area. Collectively, these results provide novel evidence supporting the use of GH after stroke to enhance known neurorestorative processes within the peri-infarct region, leading to an improvement in motor function.

In our previous study, we demonstrated that GH treatment post-stroke stimulates cognitive recovery in mice [39]. However, we did not investigate whether GH could improve motor function after stroke. Currently, therapies that promote functional motor recovery after stroke are exclusively limited to physical rehabilitation and secondary prevention, with only a modest degree of recovery [45]. While rehabilitation plays an important role in recovery from stroke, a pharmacological therapy to enhance this recovery would be highly desirable. GH is a particularly interesting option due to its approval profile, efficacy and safety. Furthermore, there is now building evidence demonstrating that GH treatment in addition to standard rehabilitation can significantly contribute to the motor recovery of an acquired brain injury [9-24,37,46,47]. For instance, Heredia et al. [18,37] observed that administration of GH subcutaneously together with rehabilitation significantly improved motor function in rats as measured by the paw-reaching-for-food task. Therefore, we were motivated to extend the existing preclinical literature to consider GH treatment for its ability to ameliorate motor impairments after stroke [14].

In the present study, we aimed to investigate the effect of $\mathrm{GH}$ alone on motor function using a photothrombotic stroke model. Specifically, we utilised a battery of tests to assess the impact of GH on motor function. The cylinder and grid walk tests are standard motor function assessments, which have been extensively validated and used in experimental stroke studies [48]. As expected, photothrombotic vascular occlusion of the motor and somatosensory cortices resulted in a clear impairment of motor function at 1-day post-stroke, which persisted for up to 30 days. The stroke mice showed preferential use of the unaffected forelimb and an increase in foot faults when using the impaired limb(s). Critically, GH treatment had a significant effect on enhancing recovery from these motor deficits at 30 days post-stroke, ameliorating the preferential use of the unaffected limb and reduction in the number of foot fault errors, thus confirming our primary hypothesis. It should be noted that our findings differ from the results from a study conducted by Pathipati et al. [14]. Although they found minor positive effects on motor recovery as assessed by a forepaw inhibition test, they did not observe any significant difference in forelimb asymmetry (cylinder task) after stroke between the GH and vehicle treatment groups. This discrepancy may be accounted for by different experimental stroke models (photothrombotic versus middle cerebral artery occlusion) and GH delivery (subcutaneous versus intracerebroventricular). In addition, we identified that GH treatment enhanced circulating levels of IGF-1 and its primary circulating binding protein, IGFBP-3. Previous studies have demonstrated the effect of IGF-1, a primary mediator of GH, on improving motor function after stroke [49,50]. Our data also suggests that higher circulatory levels of IGF-1 are associated with better motor outcomes.

To extend our understanding of the mechanisms behind the positive effects of $\mathrm{GH}$ on motor function, we also examined the impact of GH in known neurorestorative processes. Specifically, we 
focused on proliferation of progenitor cells, neurogenesis, synaptic plasticity and cerebrovascular remodelling. We observed a significant reduction in the tissue loss from the ipsilateral hemisphere at Bregma $0.0 \mathrm{~mm}$ in stroke mice treated with $\mathrm{GH}$, which is consistent with our previous observation [39]. To interpret these results, we have to consider that in this study, we started the GH treatment at 48 $\mathrm{h}$ post-stroke. At this time point, most of the neurons within the infarct would have died [51] and therefore, we would not link the decrease in tissue loss to a neuroprotective effect of GH. Instead, we would suggest that the reduction of tissue loss of the ipsilateral hemisphere is attributed to an increase in neurorestorative processes. To support our hypothesis, we used BrdU tagging to assess proliferating cells. We observed an increased number of BrdU-positive cells within the peri-infarct regions in stroke mice treated with GH, which is consistent with previous studies demonstrating that GH promotes cell proliferation within the central nervous system [52,53]. Critically, these progenitor cells are known to release neurotrophic factors to provide an environment which may contribute to neural network remodelling and functional recovery [54,55].

We then studied the fate of these newly proliferating cells. Firstly, we analysed the number of BrdU-NeuN-positive cells and we observed an increase in the number of these cells in stroke mice treated with GH. We would interpret that the new proliferating cells have differentiated (or matured) into neurons, supporting the idea that GH promotes neurogenesis after stroke [56]. Secondly, we considered the levels of expression of DCX, a protein mainly expressed by immature neurons in neurogenic niches [57-59]. Interestingly, previous studies have demonstrated that the number of DCX-positive cells positively correlates with recovery from functional deficits after stroke and, on the other hand, conditional ablation of DCX deteriorates both short- and long-term functional outcomes post-stroke [60-62]. Specifically, Jin et al. [61] showed that depletion of DCX exacerbated sensorimotor behavioural deficits measured by rotarod, limb placing and elevated body swing tests. Here, we showed that GH treatment in stroke mice also resulted in a significant increase in DCX-positive structures and protein levels within the peri-infarct region. The ability for GH to promote neurogenesis within the peri-infarct region after stroke is a critical finding, as previous studies reported an association between functional motor recovery and the number of newly born neurons in the motor and somatosensory cortex after ischemic injury [63].

Synaptic plasticity is also known to play a critical role in recovery post-stroke [64]. We investigated the AMPA receptor subunit GluR1, which is implicated in synapse formation, stabilisation and plasticity [65-67]. Previous studies have indicated that an enhancement in synaptic plasticity, specifically AMPA signalling, promotes motor recovery after stroke [68]. Clarkson et al. [68] showed that positive allosteric modulators of AMPA receptors enhance motor recovery when administered after stroke, while AMPA receptor antagonists impair motor recovery in a photothrombotic stroke model. Here, we identified an increase in GluR1-positive structures and protein levels within the peri-infarct region post-stroke in the GH-treated group. This finding further supports that GH plays an important role in synaptogenesis after stroke, as we previously observed an increase in the protein levels and density of synapsin-1 after GH treatment in a stroke model [39].

Post-stroke angiogenesis is an essential process to restore brain function, leading to functional recovery [69]. Over several weeks after stroke, spontaneous proliferation of capillary endothelial cells and a gradual increase of revascularisation had been observed [70-72]. Furthermore, most of the neurorestorative agents that improve functional outcomes after stroke or brain injury increase angiogenesis [73-77]. For instance, Chen et al. demonstrated that statins effectively enhanced motor function and this beneficial effect appeared to be mediated by an increase in angiogenesis, neurogenesis and synaptogenesis $[76,78]$. In addition, $\mathrm{GH}$ has been previously associated with angiogenesis in various areas of the brain. Sonntag et al. demonstrated that GH treatment increases cerebrocortical arteriolar density in aged rats [79]. It is therefore reasonable to propose that angiogenesis might be upregulated in the brain after GH treatment and may contribute to the improvement in motor function. Here, we analysed vessel density in the peri-infarct area using immunofluorescence labelled tomato-Lectin, which binds to glycoproteins located in the glycocalyx and in the basal membrane 
of endothelial cells [80]. Our results indicate that GH increases vessel density and area coverage at 30 days post-stroke. Critically, we observed an increase in the number of BrdU-Lectin-positive cells in the mice treated with GH following stroke, suggesting that GH has the ability to enhance angiogenesis. These findings align with our previous study, where we showed that GH has a positive effect on cerebrovascular remodelling by increased density and area coverage of both cluster of differentiation 31 (CD31) and collagen-IV-positive cells, which are typical endothelial cell markers commonly used to identify blood vessels.

One potential limitation of this study is that we did not consider the effect of GH on inflammatory processes after stroke. It is well documented that neuroinflammation also plays an important role in the pathophysiology of acute brain ischemia. Such phenomena are characterised by rapid activation of microglia, astrogliosis, infiltration of peripheral immune cells and production of pro-inflammatory cytokines [81-87]. Interestingly, GH has been previously demonstrated to induce gliogenesis [11]. It would certainly be worthwhile to investigate the effect of GH on neuroinflammatory processes after stroke in future studies.

In conclusion, in this study we demonstrated that peripheral GH treatment improves motor function post-stroke. This motor improvement is associated with enhancement of neurorestorative processes such as cell proliferation, neurogenesis, synaptic plasticity and angiogenesis. Collectively, our results reinforce the concept of using GH as a useful therapeutic tool in promoting brain recovery post-stroke. This may be clinically relevant as there are studies documenting high incidence of GH dysregulation after stroke [88-90]. While our results are encouraging and support earlier promising results from our group and others, further research should consider how long after the initial stroke we could start the treatment, what would be the optimal dose and timing required to promote functional recovery and how long after the cessation of the treatment do the positive outcomes persist, as well as the interaction of the treatment with common comorbidities. Further, the usage of GH as an adjuvant during rehabilitation after stroke should be considered. We propose that $\mathrm{GH}$ appears to represent a promising therapeutic intervention after stroke and should be considered for clinical studies.

\section{Materials and Methods}

\subsection{Animals}

Male C57BL/ 6 mice ( 10 weeks; $n=48$ ) were provided by the Animal Services Unit at the University of Newcastle (Newcastle, New South Wales, Australia). Mice were housed in cages with food and water available ad libitum in a temperature- $\left(21^{\circ} \mathrm{C} \pm 1\right)$ and humidity-controlled environment. The room lighting was set on a 12:12 h reverse light-dark cycle with lights on at 19:00. All animal procedures were conducted during the dark phase. Prior to the initiation of the experiments, mice were allowed to acclimatise to the environment for seven days. Experiments were approved by the University of Newcastle Animal Care and Ethics Committee (A-2014-432, 23 November 2015) and conducted in accordance with the New South Wales Animals Research Act and the Australian Code of Practice for the use of animals for scientific purposes. The ARRIVE guidelines (Animal Research: Reporting of In Vivo Experiments) were adhered for all animal procedures. Mice were randomised into the experimental groups. Behavioural assessments, histological and biochemistry analyses were performed in a blinded manner (see Supplementary Figure S1 for details about animal number and inclusion/exclusion criteria).

\subsection{Sample Size Calculation}

Sample size was estimated using G*Power 3.1 software (Heinrich Heine University Düsseldorf, Düsseldorf, Germany). Calculations were made based on previous data on rhGH treatment after experimental stroke [39], we obtained an effect size of $d=1.6$. Allowing a type 1 error of $5 \%, \alpha=0.05$, with the power of $80 \%, \beta=0.2$, we calculated a sample size of 8 animals per group. 


\subsection{Experimental Design}

The first cohort of mice $(n=24)$ was used to investigate the neurorestorative effects of rhGH in promoting motor function recovery, and to explore the underlying mechanisms using histological analysis (see Figure 1A for timeline). On Day 0, all mice underwent photothrombotic occlusion. Treatment with rhGH (1.4 mg/kg body weight per day) or saline began on Day 2. rhGH was delivered subcutaneously via mini-osmotic pumps and continued for 28 days. At day 3 post-stroke, mice were injected with BrdU (50 mg/kg body weight/day, Sigma-Aldrich, St. Louis, MO, USA), continuing for 5 consecutive days. Motor function was assessed one day prior to stroke (pre-stroke), Day 2 (post-stroke) and at 29 days post-stroke (post-treatment). On day 30, mice were euthanised using sodium pentabarbitol. Plasma samples were collected for analysis of insulin-like growth factor 1 (IGF-1) and insulin-like growth factor-binding protein 3 (IGFBP-3) levels using enzyme-linked immunosorbent assay (ELISA) kits (R\&D systems, minneapolis, MN, USA). After blood was collected, mice were perfused, and brains were collected for histological analysis.

The second cohort of mice $(n=24)$ was generated for protein biochemical analysis of the peri-infarct territory. On Day 0, all mice were randomly allocated to receive either photothrombotic occlusion or sham surgery. Treatment with $\mathrm{rhGH}(1.4 \mathrm{mg} / \mathrm{kg}$ body weight per day, or saline control) or saline began on Day 2, subcutaneously via mini-osmotic pumps for 28 days. Mice were sacrificed on day 30 and brains were collected for biochemical analysis.

\subsection{Photothrombotic Occlusion}

Photothrombotic occlusion was performed as described previously [91-93]. Firstly, mice were anesthetized with $2 \%$ isoflurane and placed on a temperature-controlled $\left(37^{\circ} \mathrm{C} \pm 1\right)$ stereotaxic frame. Mice received an intraperitoneal injection of Rose Bengal $(200 \mu \mathrm{L}, 10 \mathrm{mg} / \mathrm{mL}$ solution in sterile saline, Sigma-Aldrich, USA) or sterile saline $(0.9 \% \mathrm{NaCl}$, Pfizer, Sydney, Australia) before the skull was exposed by incision of the skin. At $8 \mathrm{~min}$ post-injection, a cold light source ( $4.5 \mathrm{~mm}$ diameter) was placed on the skull at $2.2 \mathrm{~mm}$ left lateral of Bregma $0.0 \mathrm{~mm}$ for $15 \mathrm{~min}$.

\subsection{Mini-Osmotic Pump Placement}

Mini-osmotic pump placement was performed as previously described [94]. Briefly, at $48 \mathrm{~h}$ post-stroke, mice were anaesthetised with $2 \%$ isoflurane. An incision was made in the skin between the scapulae to create a subcutaneous space for the mini-osmotic pumps (Model 2004, Alzet, Cupertino, CA, USA). The mini-osmotic pumps were filled with $200 \mu \mathrm{L}$ of either $\mathrm{rhGH}$ (Somatropin $10 \mathrm{mg} / 1.5 \mathrm{~mL}$, SciTropin A, SciGen, Australia) or sterile saline. The pumps deliver $0.25 \mu \mathrm{L} /$ hour for 28 days $(0.04 \mathrm{mg}$ rhGH per day). After the pump was placed into the subcutaneous space, the skin incision was closed with staples. The surgical procedure was performed in a temperature-controlled environment $\left(37^{\circ} \mathrm{C} \pm 1\right)$.

\subsection{Motor Test}

As outlined in the experimental design, motor tests were performed one day pre-stroke, one day post-stroke and at 29 days post-stroke.

Forelimb asymmetry was assessed by a cylinder test as previously described [86,92,95]. Briefly, each mouse was placed in a glass cylinder. The locomotor activity was recorded using video cameras from two different angles. The first forelimb to touch the wall of the cylinder during a full rear was scored as a wall placement. When both forelimbs (left and right) simultaneously touched the wall of the cylinder, it was considered as one placement for each forelimb. A total of 20 forelimb placements per mouse were scored by a blinded researcher. The forelimb asymmetry score was calculated as the ratio of non-impaired forelimb placement minus impaired forelimb placement to total forelimb placement.

Deficits in limb placement were evaluated by the grid walk test as previously described [92,95]. Briefly, each mouse was placed on a grid $\left(2 \times 2 \mathrm{~cm}^{2}\right)$ elevated from the ground. The locomotor activity was recorded using video cameras from two different angles. A 'foot fault' was scored when a mouse 
failed to place their paw on the bars of the grid. The number of foot faults on each side was counted over a total of 60 steps by a blinded researcher. A foot fault index was calculated as the ratio of non-impaired foot faults minus impaired foot faults to the total number of steps.

\subsection{ELISA}

Commercially available ELISA kits were used to measure plasma levels of IGF-1 (mouse/rat IGF-1 Quantikine ELISA (MG100; R\&D systems, minneapolis, MN, USA) and IGFBP-3 (mouse IGFBP-3 ELISA (EMIGFBP3; Thermo Fisher Scientific, Scoresby, Victoria, Australia), according to the manufacturer's instructions.

\subsection{Histological Analysis}

The first cohort of mice were perfused transcardially using $0.9 \%$ saline followed by $4 \%$ paraformaldehyde ( $\mathrm{pH} 7.4$, both solutions kept in ice). Brains were collected and post-fixed for $4 \mathrm{~h}$ in $4 \%$ paraformaldehyde. Brains were then transferred to a $12.5 \%$ sucrose solution in $0.1 \mathrm{M}$ PBS and stored until sliced. Brains were sliced (coronal sections) using a freezing microtome (Leica, North Ryde, NSW, Australia) at a thickness of $30 \mu \mathrm{m}$ and kept in an antifreeze solution at $4{ }^{\circ} \mathrm{C}$. Fixed brains were later used for histological analyses.

Cresyl violet staining was performed as previously described [86]. Coronal brain sections ( 2 sections per brain, Bregma 0.0 and $-2.0 \mathrm{~mm}$ ) were mounted on glass slides and allowed to dry for $1 \mathrm{~h}$. Sections were defatted in chloroform: consisting of submersion in ethanol solution for $8 \mathrm{~min}$, followed by rehydration in absolute ethanol, $95 \%$ ethanol and $70 \%$ ethanol. Sections were stained in Cresyl Violet solution for $15 \mathrm{~min}$. Then, sections were washed in 70\% ethanol, $95 \%$ ethanol, differentiating solution and absolute ethanol. Finally, the sections were cleared in xylene and cover slipped.

Immunofluorescence staining was performed as previously described $[85,96]$. Free-floating fixed sections were rinsed in PBS, and 3\% bovine serum albumin was used to block non-specific binding. For BrdU staining, antigen retrieval was performed before the blocking step, as follows: $10 \operatorname{min~} \mathrm{HCl}(1 \mathrm{M})$ incubation on ice, $10 \mathrm{~min} \mathrm{HCl}(2 \mathrm{M})$ incubation at room temperature, $20 \mathrm{~min} \mathrm{HCl}(2 \mathrm{M})$ incubation at $37^{\circ} \mathrm{C}, 10 \mathrm{~min}$ borate buffer $(0.1 \mathrm{M})$ incubation at room temperature and three washes in PBS $+0.1 \%$ triton. Sections were incubated with the appropriate primary antibody (DCX, GluR1, BrdU, NeuN, (see Table 1) overnight at $4{ }^{\circ} \mathrm{C}$. After the primary antibody incubation, sections were washed and incubated in corresponding secondary antibodies for $2 \mathrm{~h}$ at room temperature (see Table 1 for antibody concentrations and acronym description). For blood vessel detection, lectin staining was performed together with the secondary antibody incubation. Finally, brain sections were mounted on glass slides, air-dried and cover slipped.

\subsection{Image Acquisition and Analysis}

Cresyl Violet images were acquired at 20× magnification using Aperio AT2 (Leica, Wetzlar, Germany). The estimated tissue loss area was determined as the area of contralateral hemisphere area of ipsilateral hemisphere using ImageJ software (National Institutes of Health, Bethesda, MD, USA). Bregma levels of 0.0 and $-2.0 \mathrm{~mm}$ were used for analyses.

Co-immunofluorescence high-resolution images of the peri-infarct area (Figure 1B) were taken on a Leica TCS SP8 confocal microscope with a Leica HC PLC APO 10×/0.40 objective. For the peri-infarct region of interest, $30 \mu \mathrm{m}$ z-stacks with a step size of $1 \mu \mathrm{m}$ were taken. Imaging parameters (laser power, resolution and gain) were held constant throughout all imaging sessions. Exhaustive automated BrdU and NeuN cell counts were performed using ImageJ software (Supplementary Figure S2A). For analysis of DCX and GluR1 labelling, we performed thresholding analyses and chose the optimal pixel intensity that clearly reflected the immunofluorescence signal (Supplementary Figure S2C). To measure vessel coverage (\% Lectin-positive area), Lectin emission image was uniformly thresholded at a high stringency (Supplementary Figure S2B). The area of vessel coverage was expressed as a percentage of the overall image (ImageJ Software). For BrdU-NeuN-positive and BrdU-Lectin-positive 
co-labelling, we used the plugin 'colocalization' for ImageJ. The colocalised points of two 8-bits images were highlighted by this plugin and will appear as black points (Supplementary Figure S2D).

\subsection{Protein Extraction and Western Blotting}

The second cohort of mice were transcardially perfused with cold $0.9 \%$ saline for $3 \mathrm{~min}$. Brains were dissected, snap frozen in isopentane and stored at $-80^{\circ} \mathrm{C}$. A cryostat $\left(-20^{\circ} \mathrm{C}\right)$ was used to slice the brains (coronal sections) at a thickness of $200 \mu \mathrm{m}$. The peri-infarct territory $\left(2 \mathrm{~mm}^{2}\right.$ around infarct core, Bregma +1.0 to $-1.0 \mathrm{~mm}$ ) of each section was punched using a $1 \mathrm{~mm}$ tissue punch. Samples were stored in $-80^{\circ} \mathrm{C}$ for further biochemical analysis.

Protein extraction and subsequent western blotting were performed as previously described [91,97,98]. Briefly, peri-infarct tissue samples (Figure 1B) were sonicated in $300 \mu \mathrm{L}$ lysis buffer. The components of the lysis buffer were $1 \%$ SDS, $1 \mathrm{mM}$ ethylenediaminetetraacetic acid, $1 \mathrm{mM}$ dithiothreitol, $80 \mu \mathrm{M}$ ammoniummolybdate, $1 \mathrm{mM}$ sodium pyrophosphate, $1 \mathrm{mM}$ sodium vanadate, $5 \mathrm{mM}$ $\beta$-glycerolphosphate, 1 protease inhibitor cocktail tablet, and 1 phosphatase inhibitor cocktail tablet in $50 \mathrm{mM}$ tris(hydroxymethyl)aminomethane buffer $\mathrm{pH}$ 7.4. The samples were centrifuged at $14,000 \times g$ for $20 \mathrm{~min}$ at $4{ }^{\circ} \mathrm{C}$. Then, supernatants were collected into new tubes to separate from the pellet fractions. For determination of protein concentration, a Pierce bicinchoninic acidprotein assay kit was used (Thermo Fisher Scientific, USA) per the manufacturer's instructions. All supernatant samples were adjusted to $1.5 \mathrm{mg} / \mathrm{mL}$. The samples were mixed with sample buffer ( $2 \%$ SDS, $50 \mathrm{mM}$ Tris, $10 \%$ glycerol, $1 \%$ dithiothreitol, $0.1 \%$ bromophenol blue, $\mathrm{pH} 6.8$ ). For western blotting, $15 \mu \mathrm{g}$ of lysate was loaded per lane and electrophoresed to Biorad Criterion TGX (Tris-Glycine eXtended) Stain-Free $4 \%-20 \%$ gels. Gels were transferred to polyvinylidene fluoride membranes. After transferring, membranes were blocked with $5 \%$ skim milk for $1 \mathrm{~h}$ at room temperature. Then, membranes were incubated with the primary antibody (DCX or GluR1, see Table 1 for antibody concentrations) in a rocking plate overnight at $4{ }^{\circ} \mathrm{C}$. The following day, membranes were washed with tris-buffered saline, $0.1 \%$ Tween and incubated with the appropriate secondary antibody for $1 \mathrm{~h}$ at room temperature. Membranes were visualised on an Amersham Imager 600 (GE Healthcare Life Sciences, Pittsburgh, PA, USA) using Luminata Classico western blotting detection reagent. The Amersham Imager 600 analysis software was (GE Healthcare Life Sciences, Pittsburgh, PA, USA) used to analyse the density of the bands. 
Table 1. List of antibodies used for western blot and immunofluorescence analyses.

\begin{tabular}{|c|c|c|c|c|}
\hline Targets & Description & Sources of Antibodies & Application & Dilution \\
\hline BrdU & $\begin{array}{c}\text { Bromodeoxyuridine (BrdU) is used as a marker for the } \\
\text { proliferation of cells [40]. It is a synthetic nucleoside } \\
\text { analog of thymidine that is incorporated into the DNA } \\
\text { of actively replicating cells. }\end{array}$ & Sigma-Aldrich, mouse anti-BrdU, \#B8434 & IF & 1:1000 \\
\hline NeuN & $\begin{array}{l}\text { Neuronal nuclei (NeuN) is a nuclear protein expressed } \\
\text { in most neurons of the nervous systems [99]. It is a } \\
\text { marker for mature neurons. }\end{array}$ & Cell Signalling, rabbit anti-NeuN (D3S31), \#12943 & IF & 1:1000 \\
\hline DCX & $\begin{array}{l}\text { Doublecortin (DCX) is a microtubule associated protein } \\
\text { that stabilises and bundles microtubules. It is expressed } \\
\text { by neuronal precursor cells and immature neurons [41] }\end{array}$ & abcam, rabbit anti-doublecortin, \#ab18723 & $\begin{array}{l}\text { WB } \\
\text { IF }\end{array}$ & $\begin{array}{l}1: 1000 \\
1: 1000\end{array}$ \\
\hline GluR1 & $\begin{array}{l}\text { AMPA receptor 1 (GluR1) is an ionotropic } \\
\text { glutamate-gated ion channel. GluR1 is implicated in } \\
\text { synapse formation, stabilisation and plasticity [44]. } \\
\text { GluR1 is necessary for expression of long-term } \\
\text { potentiation in the hippocampus and formation of } \\
\text { short-term memory [100]. }\end{array}$ & $\begin{array}{l}\text { Cell Signalling, rabbit anti-AMPA Receptor } 1 \\
\text { (GluA1), \#13185 }\end{array}$ & $\begin{array}{l}\text { WB } \\
\text { IF }\end{array}$ & $\begin{array}{l}1: 2000 \\
1: 1000\end{array}$ \\
\hline$\beta$-actin & $\beta$-actin is a cytoskeletal housekeeping protein. & $\begin{array}{l}\text { Sigma-Aldrich, Monoclonal Anti- } \beta \text {-actin-HRP } \\
\text { antibody, A3854 }\end{array}$ & WB & 1:50000 \\
\hline NeuroTrace & $\begin{array}{l}\text { NeuroTrace fluorescent Nissl stain is selective for the } \\
\text { Nissl substance present in neurons [101]. Nissl } \\
\text { substance is composed of ribosomal RNA associated } \\
\text { with the rough endoplasmic reticulum in neuronal } \\
\text { perikarya and dendrites. }\end{array}$ & $\begin{array}{l}\text { ThermoFisher Scientific, NeuroTrace }{ }^{\mathrm{TM}} \text { 640/660 } \\
\text { Deep-Red Fluorescent Nissl Stain, \#N21483 }\end{array}$ & IF & 1:1000 \\
\hline Lectin & $\begin{array}{l}\text { Tomato lectin is a common stain for blood vessels. } \\
\text { Lectin binds to carbohydrate components of endothelial } \\
\text { cells [80]. }\end{array}$ & $\begin{array}{l}\text { Vecton Laboratories, DyLight } 649 \text { Lycopersicon } \\
\text { esculentum (Tomato) lectin \#DL-1178 }\end{array}$ & IF & $1: 1000$ \\
\hline Rabbit IgG & Secondary antibody. & $\begin{array}{c}\text { Biorad, Anti-Rabbit-HRP antibody, \#170-6515 } \\
\text { ThermoFisher Scientific, anti-Rabbit IgG (H + L) } \\
\text { Highly Cross-Adsorbed Secondary Antibody, } \\
\text { Alexa Fluor 488, \#A21206 }\end{array}$ & $\begin{array}{l}\text { WB } \\
\text { IF }\end{array}$ & $\begin{array}{l}1: 7500 \\
1: 400\end{array}$ \\
\hline Mouse IgG & Secondary antibody. & $\begin{array}{c}\text { ThermoFisher Scientific, anti-Mouse IgG }(\mathrm{H}+\mathrm{L}) \\
\text { Highly Cross-Adsorbed Secondary Antibody, } \\
\text { Alexa Fluor 594, \#A21203 }\end{array}$ & IF & 1:400 \\
\hline
\end{tabular}

WB, western blot; IF, immunofluorescence. 


\subsection{Statistical Analyses}

All data were analysed using GraphPad Prism v7.02 (GraphPad Software, San Diego, CA, USA) and are expressed as mean \pm standard deviation (SD). Tissue loss and motor test data were analysed using 2-way analysis of variance (ANOVA) followed by Sidak multiple comparisons. ELISA, western blotting and immunofluorescence labelling were analysed using 2-tailed t-tests. Pearson correlation was used to determine the association between motor performance and plasma IGF-1. A $p$-value $<0.05$ was considered statistically significant.

Supplementary Materials: Supplementary Materials can be found at http://www.mdpi.com/1422-0067/21/2/606/s1.

Author Contributions: Conceptualization, S.S.-B., J.I and L.K.O.; Data curation, S.S.-B. and L.K.O; Formal analysis, S.S.-B., J.I. and L.K.O.; Funding acquisition, F.R.W., M.N., J.I. and L.K.O.; Methodology, S.S.-B. and L.K.O.; Supervision, F.RW., M.N., J.I. and L.K.O.; Writing-original draft, S.S.-B and L.K.O.; Writing-review and editing, S.S.B., N.D.Å., P.C., F.R.W, M.N., J.I. and L.K.O. All authors have read and agreed to the published version of the manuscript.

Funding: This study was funded by the Swedish Government (ALFGBG-74390), University of Gothenburg, Hunter Medical Research Institute, Faculty of Health and Medicine Pilot Grant, Priority Research Centre for Stroke and Brain Injury Research Support Grant, Mary Costello Alzheimer's Pilot Grant and The University of Newcastle, Australia. L.K.O. and S.S.-B. also acknowledge support from Research Advantage for ECR Higher Degree by Research (HDR) Scholarship and Greaves Family Postgraduate Scholarships in Medical Research. N.D.Å. was supported by grants from the Swedish state under the agreement between the Swedish Government (ALFGBG-719761, ALFGBG-751111).

Acknowledgments: We would like to acknowledge the insights and comments provided by Rebecca Hood on early versions of the manuscript.

Conflicts of Interest: The authors declare no conflict of interest. The funders had no role in the design of the study; in the collection, analyses, or interpretation of data; in the writing of the manuscript, or in the decision to publish the results.

\section{Abbreviations}

$\begin{array}{ll}\text { GH } & \text { Growth hormone } \\ \text { rhGH } & \text { Recombinant human growth hormone } \\ \text { BrdU } & \text { Bromodeoxyuridine } \\ \text { IGF-1 } & \text { Insulin-like growth factor 1 } \\ \text { IGFBP-3 } & \text { Insulin-like growth factor-binding protein 3 } \\ \text { CL } & \text { Contralateral } \\ \text { IL } & \text { Ipsilateral } \\ \text { NeuN } & \text { Neuronal nuclei } \\ \text { DCX } & \text { Doublecortin } \\ \text { GluR1 } & \text { AMPA Receptor 1 } \\ \text { CD31 } & \text { Cluster of differentiation 31 } \\ \text { ELISA } & \text { Enzyme-linked immunosorbent assay }\end{array}$

\section{References}

1. Mackay, J.; Mensah, G.A. The Atlas of Heart Disease and Stroke; World Health Organization: Geneva, Switzerland, 2004.

2. Hankey, G.J.; Jamrozik, K.; Broadhurst, R.J.; Forbes, S.; Anderson, C.S. Long-term disability after first-ever stroke and related prognostic factors in the Perth Community Stroke Study, 1989-1990. Stroke 2002, 33, 1034-1040. [CrossRef]

3. Langhorne, P.; Bernhardt, J.; Kwakkel, G. Stroke rehabilitation. Lancet 2011, 377, 1693-1702. [CrossRef]

4. Langhorne, P.; Coupar, F.; Pollock, A. Motor recovery after stroke: A systematic review. Lancet Neurol. 2009, 8, 741-754. [CrossRef]

5. Johansson, B.B. Current trends in stroke rehabilitation: A review with focus on brain plasticity. Acta Neurol. Scand. 2011, 123, 147-159. [CrossRef] [PubMed] 
6. Arya, K.N.; Pandian, S.; Verma, R.; Garg, R. Movement therapy induced neural reorganization and motor recovery in stroke: A review. J. Bodyw. Mov. Ther. 2011, 15, 528-537. [CrossRef] [PubMed]

7. Brewer, L.; Horgan, F.; Hickey, A.; Williams, D. Stroke rehabilitation: Recent advances and future therapies. QJM 2013, 106, 11-25. [CrossRef] [PubMed]

8. Bernhardt, J.; Langhorne, P.; Lindley, R.I.; Thrift, A.G.; Ellery, F.; Collier, J.; Churilov, L.; Moodie, M.; Dewey, H.; Donnan, G. Efficacy and safety of very early mobilisation within $24 \mathrm{~h}$ of stroke onset (AVERT): A randomised controlled trial. Lancet 2015, 386, 46-55.

9. Scheepens, A.; Sirimanne, E.S.; Breier, B.H.; Clark, R.G.; Gluckman, P.D.; Williams, C.E. Growth hormone as a neuronal rescue factor during recovery from CNS injury. Neuroscience 2001, 104, 677-687. [CrossRef]

10. Shin, N.H.; Lee, E.; Kim, J.W.; Kwon, B.S.; Jung, M.K.; Jee, Y.H.; Kim, J.; Bae, S.R.; Chang, Y.P. Protective effect of growth hormone on neuronal apoptosis after hypoxia-ischemia in the neonatal rat brain. Neurosci. Lett. 2004, 354, 64-68. [CrossRef]

11. Åberg, N.D.; Brywe, K.G.; Isgaard, J. Aspects of Growth Hormone and Insulin-Like Growth Factor-I Related to Neuroprotection, Regeneration, and Functional Plasticity in the Adult Brain. Sci. World J. 2006, 6, 53-80. [CrossRef]

12. Isgaard, J.; Aberg, D.; Nilsson, M. Protective and regenerative effects of the GH/IGF-I axis on the brain. Minerva Endocrinol. 2007, 32, 103-113. [PubMed]

13. Christophidis, L.J.; Gorba, T.; Gustavsson, M.; Williams, C.E.; Werther, G.A.; Russo, V.C.; Scheepens, A. Growth hormone receptor immunoreactivity is increased in the subventricular zone of juvenile rat brain after focal ischemia: A potential role for growth hormone in injury-induced neurogenesis. Growth Horm. IGF Res. 2009, 19, 497-506. [CrossRef] [PubMed]

14. Pathipati, P.; Surus, A.; Williams, C.E.; Scheepens, A. Delayed and chronic treatment with growth hormone after endothelin-induced stroke in the adult rat. Behav. Brain Res. 2009, 204, 93-101. [CrossRef] [PubMed]

15. Devesa, P.; Reimunde, P.; Gallego, R.; Devesa, J.; Arce, V.M. Growth hormone (GH) treatment may cooperate with locally-produced $\mathrm{GH}$ in increasing the proliferative response of hippocampal progenitors to kainate-induced injury. Brain Inj. 2011, 25, 503-510. [CrossRef] [PubMed]

16. Li, R.C.; Guo, S.Z.; Raccurt, M.; Moudilou, E.; Morel, G.; Brittian, K.R.; Gozal, D. Exogenous growth hormone attenuates cognitive deficits induced by intermittent hypoxia in rats. Neuroscience 2011, 196, 237-250. [CrossRef]

17. Alba-Betancourt, C.; Luna-Acosta, J.L.; Ramírez-Martínez, C.E.; Ávila-González, D.; Granados-Ávalos, E.; Carranza, M.; Martinez-Coria, H.; Arámburo, C.; Luna, M. Neuro-protective effects of growth hormone (GH) after hypoxia-ischemia injury in embryonic chicken cerebellum. Gen. Comp. Endocrinol. 2013, 183, 17-31. [CrossRef]

18. Heredia, M.; Palomero, J.; De La Fuente, A.; Criado, J.M.; Yajeya, J.; Devesa, J.; Devesa, P.; Vicente-Villardón, J.L.; Riolobos, A.S. Motor Improvement of Skilled Forelimb Use Induced by Treatment with Growth Hormone and Rehabilitation Is Dependent on the Onset of the Treatment after Cortical Ablation. Neural Plast. 2018, 2018, 6125901. [CrossRef]

19. Devesa, J.; Reimunde, P.; Devesa, A.; Souto, S.; Lopez-Amado, M.; Devesa, P.; Arce, V.; Arce, V. Recovery from neurological sequelae secondary to oncological brain surgery in an adult growth hormone-deficient patient after growth hormone treatment. J. Rehabil. Med. 2009, 41, 775-777. [CrossRef]

20. High, W.M.; Briones-Galang, M.; Clark, J.A.; Gilkison, C.; Mossberg, K.A.; Zgaljardic, D.J.; Masel, B.E.; Urban, R.J. Effect of Growth Hormone Replacement Therapy on Cognition after Traumatic Brain Injury. J. Neurotrauma 2010, 27, 1565-1575. [CrossRef]

21. Reimunde, P.; Quintana, A.; Castanon, B.; Casteleiro, N.; Vilarnovo, Z.; Otero, A.; Devesa, A.; Otero-Cepeda, X.L.; Devesa, J. Effects of growth hormone (GH) replacement and cognitive rehabilitation in patients with cognitive disorders after traumatic brain injury. Brain Inj. 2011, 25, 65-73. [CrossRef]

22. Moreau, O.K.; Cortet-Rudelli, C.; Yollin, E.; Merlen, E.; Daveluy, W.; Rousseaux, M. Growth Hormone Replacement Therapy in Patients with Traumatic Brain Injury. J. Neurotrauma 2013, 30, 998-1006. [CrossRef] [PubMed]

23. Song, J.; Park, K.; Lee, H.; Kim, M. The Effect of Recombinant Human Growth Hormone Therapy in Patients with Completed Stroke: A Pilot Trial. Ann. Rehabil. Med. 2012, 36, 447-457. [CrossRef] [PubMed]

24. Devesa, J.; Devesa, P.; Reimunde, P.; Arce, V. Growth Hormone and Kynesitherapy for Brain Injury Recovery. In Brain Injury_-Pathogenesis, Monitoring, Recovery and Management; IntechOpen: London, UK, 2012. 
25. Lobie, P.E.; Garcia-Aragon, J.; Lincoln, D.T.; Barnard, R.; Wilcox, J.N.; Waters, M.J. Localization and ontogeny of growth hormone receptor gene expression in the central nervous system. Dev. Brain Res. 1993, 74, 225-233. [CrossRef]

26. Blackmore, D.G.; Reynolds, B.A.; Golmohammadi, M.G.; Large, B.; Aguilar, R.M.; Haro, L.; Waters, M.J.; Rietze, R.L. Growth hormone responsive neural precursor cells reside within the adult mammalian brain. Sci. Rep. 2012, 2, 250. [CrossRef]

27. Bianchi, V.E.; Locatelli, V.; Rizzi, L. Neurotrophic and Neuroregenerative Effects of GH/IGF1. Int. J. Mol. Sci. 2017, 18, 2441. [CrossRef]

28. Ohab, J.J.; Carmichael, S.T. Poststroke Neurogenesis: Emerging Principles of Migration and Localization of Immature Neurons. Neuroscientist 2008, 14, 369-380. [CrossRef]

29. Dancause, N.; Barbay, S.; Frost, S.B.; Plautz, E.J.; Chen, D.; Zoubina, E.V.; Stowe, A.M.; Nudo, R.J. Extensive Cortical Rewiring after Brain Injury. J. Neurosci. 2005, 25, 10167-10179. [CrossRef]

30. Li, S.; Overman, J.J.; Katsman, D.; Kozlov, S.V.; Donnelly, C.J.; Twiss, J.L.; Giger, R.J.; Coppola, G.; Geschwind, D.H.; Carmichael, S.T. An age-related sprouting transcriptome provides molecular control of axonal sprouting after stroke. Nat. Neurosci. 2010, 13, 1496-1504. [CrossRef]

31. Jin, K.; minami, M.; Lan, J.Q.; Mao, X.O.; Batteur, S.; Simon, R.P.; Greenberg, D.A. Neurogenesis in dentate subgranular zone and rostral subventricular zone after focal cerebral ischemia in the rat. Proc. Natl. Acad. Sci. USA 2001, 98, 4710-4715. [CrossRef]

32. Kannangara, T.S.; Carter, A.; Xue, Y.; Dhaliwal, J.S.; Béïque, J.C.; Lagace, D.C. Excitable Adult-Generated GABAergic Neurons Acquire Functional Innervation in the Cortex after Stroke. Stem Cell Rep. 2018, 11, 1327-1336. [CrossRef]

33. Arvidsson, A.; Collin, T.; Kirik, D.; Kokaia, Z.; Lindvall, O. Neuronal replacement from endogenous precursors in the adult brain after stroke. Nat. Med. 2002, 8, 963-970. [CrossRef] [PubMed]

34. Parent, J.M.; Vexler, Z.S.; Gong, C.; Derugin, N.; Ferriero, N.M. Rat forebrain neurogenesis and striatal neuron replacement after focal stroke. Ann. Neurol. 2002, 52, 802-813. [CrossRef] [PubMed]

35. Zhang, R.L.; Zhang, Z.G.; Zhang, L.; Chopp, M. Proliferation and differentiation of progenitor cells in the cortex and the subventricular zone in the adult rat after focal cerebral ischemia. Neuroscience 2001, 105, $33-41$. [CrossRef]

36. Gu, W.; Brannstrom, T.; Wester, P. Cortical Neurogenesis in Adult Rats after Reversible Photothrombotic Stroke. J. Cereb. Blood Flow Metab. 2000, 20, 1166-1173. [CrossRef]

37. Heredia, M.; Fuente, A.; Criado, J.; Yajeya, J.; Devesa, J.; Riolobos, A. Early growth hormone (GH) treatment promotes relevant motor functional improvement after severe frontal cortex lesion in adult rats. Behav. Brain Res. 2013, 247, 48-58. [CrossRef]

38. Heredia, M.; Rodríguez, N.; Robledo, V.S.; Criado, J.M.; De La Fuente, A.; Devesa, J.; Devesa, P.; Riolobos, A.S. Factors Involved in the Functional Motor Recovery of Rats with Cortical Ablation after GH and Rehabilitation Treatment: Cortical Cell Proliferation and Nestin and Actin Expression in the Striatum and Thalamus. Int. J. Mol. Sci. 2019, 20, 5770. [CrossRef]

39. Ong, L.K.; Chow, W.Z.; Tebay, C.; Kluge, M.; Pietrogrande, G.; Zalewska, K.; Crock, P.; Åberg, N.D.; Bivard, A.; Johnson, S.J.; et al. Growth Hormone Improves Cognitive Function After Experimental Stroke. Stroke 2018, 49, 1257-1266. [CrossRef]

40. Duque, A.; Rakic, P. Different effects of bromodeoxyuridine and $\left[{ }^{3} \mathrm{H}\right]$ thymidine incorporation into DNA on cell proliferation, position, and fate. J. Neurosci. 2011, 31, 15205-15217. [CrossRef]

41. Brown, J.P.; Couillard-Després, S.; Cooper-Kuhn, C.M.; Winkler, J.; Aigner, L.; Kuhn, H.G. Transient expression of doublecortin during adult neurogenesis. J. Comp. Neurol. 2003, 467, 1-10. [CrossRef]

42. Ayanlaja, A.A.; Xiong, Y.; Gao, Y.; Ji, G.; Tang, C.; Abdullah, Z.A.; Gao, D.S. Distinct Features of Doublecortin as a Marker of Neuronal Migration and Its Implications in Cancer Cell Mobility. Front. Mol. Neurosci. 2017, 10, 199. [CrossRef]

43. Couillard-Despres, S.; Winner, B.; Schaubeck, S.; Aigner, R.; Vroemen, M.; Weidner, N.; Bogdahn, U.; Winkler, J.; Kuhn, H.G.; Aigner, L. Doublecortin expression levels in adult brain reflect neurogenesis. Eur. J. Neurosci. 2005, 21, 1-14. [CrossRef] [PubMed]

44. Cull-Candy, S.; Kelly, L.; Farrant, M. Regulation of $\mathrm{Ca}^{2+}$-permeable AMPA receptors: Synaptic plasticity and beyond. Curr. Opin. Neurobiol. 2006, 16, 288-297. [CrossRef] [PubMed] 
45. Dobkin, B.H. Training and exercise to drive poststroke recovery. Nat. Clin. Pract. Neurol. 2008, 4, 76-85. [CrossRef] [PubMed]

46. Devesa, J.; Reimunde, P.; Devesa, P.; Barberá, M.; Arce, V. Growth hormone (GH) and brain trauma. Horm. Behav. 2013, 63, 331-344. [CrossRef]

47. Devesa, J.; Díaz-Getino, G.; Rey, P.; García-Cancela, J.; Loures, I.; Nogueiras, S.; De Mendoza, A.H.; Salgado, L.; González, M.; Pablos, T.; et al. Brain Recovery after a Plane Crash: Treatment with Growth Hormone (GH) and Neurorehabilitation: A Case Report. Int. J. Mol. Sci. 2015, 16, 30470-30482. [CrossRef]

48. Schaar, K.L.; Brenneman, M.M.; Savitz, S.I. Functional assessments in the rodent stroke model. Exp. Transl. Stroke Med. 2010, 2, 13. [CrossRef]

49. Liu, X.F.; Fawcett, J.R.; Thorne, R.G.; DeFor, T.A.; Frey, W.H. Intranasal administration of insulin-like growth factor-I bypasses the blood-brain barrier and protects against focal cerebral ischemic damage. J. Neurol. Sci. 2001, 187, 91-97. [CrossRef]

50. Zhu, W.; Fan, Y.; Frenzel, T.; Gasmi, M.; Bartus, R.T.; Young, W.L.; Yang, G.Y.; Chen, Y. Insulin Growth Factor-1 Gene Transfer Enhances Neurovascular Remodeling and Improves Long-Term Stroke Outcome in Mice. Stroke 2008, 39, 1254-1261. [CrossRef]

51. Buscemi, L.; Price, M.; Bezzi, P.; Hirt, L. Spatio-temporal overview of neuroinflammation in an experimental mouse stroke model. Sci. Rep. 2019, 9, 507. [CrossRef]

52. Åberg, N.D.; Johansson, I.; Åberg, M.A.; Lind, J.; Johansson, U.E.; Cooper-Kuhn, C.M.; Kuhn, H.G.; Isgaard, J. Peripheral administration of GH induces cell proliferation in the brain of adult hypophysectomized rats. J. Endocrinol. 2009, 201, 141-150. [CrossRef]

53. Åberg, N.D.; Lind, J.; Isgaard, J.; Kuhn, H.G. Peripheral growth hormone induces cell proliferation in the intact adult rat brain. Growth Horm. IGF Res. 2010, 20, 264-269. [CrossRef] [PubMed]

54. Li, B.; Piao, C.S.; Liu, X.Y.; Guo, W.P.; Xue, Y.Q.; Duan, W.M.; Gonzalez-Toledo, M.E.; Zhao, L.R. Brain self-protection: The role of endogenous neural progenitor cells in adult brain after cerebral cortical ischemia. Brain Res. 2010, 1327, 91-102. [CrossRef] [PubMed]

55. Zhao, L.R.; Willing, A. Enhancing endogenous capacity to repair a stroke-damaged brain: An evolving field for stroke research. Prog. Neurobiol. 2018, 5-26. [CrossRef] [PubMed]

56. Lindvall, O.; Kokaia, Z. Neurogenesis following Stroke Affecting the Adult Brain. Cold Spring Harb. Perspect. Biol. 2015, 7, a019034. [CrossRef]

57. Jin, K.; Sun, Y.; Xie, L.; Peel, A.; Mao, X.O.; Batteur, S.; Greenberg, D.A. Directed migration of neuronal precursors into the ischemic cerebral cortex and striatum. Mol. Cell. Neurosci. 2003, 24, 171-189. [CrossRef]

58. Keiner, S.; Witte, O.W.; Redecker, C. Immunocytochemical Detection of Newly Generated Neurons in the Perilesional Area of Cortical Infarcts After Intraventricular Application of Brain-Derived Neurotrophic Factor. J. Neuropathol. Exp. Neurol. 2009, 68, 83-93. [CrossRef]

59. Kunze, A.; Achilles, A.; Keiner, S.; Witte, O.W.; Redecker, C. Two distinct populations of doublecortin-positive cells in the perilesional zone of cortical infarcts. BMC Neurosci. 2015, 16, 20. [CrossRef]

60. Kunze, A.; Grass, S.; Witte, O.W.; Yamaguchi, M.; Kempermann, G.; Redecker, C. Proliferative response of distinct hippocampal progenitor cell populations after cortical infarcts in the adult brain. Neurobiol. Dis. 2006, 21, 324-332. [CrossRef]

61. Jin, K.; Wang, X.; Xie, L.; Mao, X.O.; Greenberg, D.A. Transgenic ablation of doublecortin-expressing cells suppresses adult neurogenesis and worsens stroke outcome in mice. Proc. Natl. Acad. Sci. USA 2010, 107, 7993-7998. [CrossRef]

62. Sun, F.; Wang, X.; Mao, X.; Xie, L.; Jin, K. Ablation of Neurogenesis Attenuates Recovery of Motor Function after Focal Cerebral Ischemia in Middle-Aged Mice. PLoS ONE 2012, 7, e46326. [CrossRef]

63. Ohab, J.J.; Fleming, S.; Blesch, A.; Carmichael, S.T. A Neurovascular Niche for Neurogenesis after Stroke. J. Neurosci. 2006, 26, 13007-13016. [CrossRef]

64. Murphy, T.H.; Corbett, D. Plasticity during stroke recovery: From synapse to behaviour. Nat. Rev. Neurosci. 2009, 10, 861-872. [CrossRef]

65. Hollmann, M.; Heinemann, S. Cloned Glutamate Receptors. Annu. Rev. Neurosci. 1994, 17, 31-108. [CrossRef]

66. Dingledine, R.; Borges, K.; Bowie, D.; Traynelis, S.F. The glutamate receptor ion channels. Pharmacol. Rev. 1999, 51, 7-61.

67. Lu, W.; Isozaki, K.; Roche, K.W.; Nicoll, R.A. Synaptic targeting of AMPA receptors is regulated by a CaMKII site in the first intracellular loop of GluA1. Proc. Natl. Acad. Sci. USA 2010, 107, 22266-22271. [CrossRef] 
68. Clarkson, A.N.; Overman, J.J.; Zhong, S.; Mueller, R.; Lynch, G.; Carmichael, S.T. AMPA receptor-induced local brain-derived neurotrophic factor signaling mediates motor recovery after stroke. J. Neurosci. 2011, 31, 3766-3775. [CrossRef]

69. Ergul, A.; Alhusban, A.; Fagan, S.C. Angiogenesis: A harmonized target for recovery after stroke. Stroke 2012, 43, 2270-2274. [CrossRef]

70. Li, Y.; Lu, Z.; Keogh, C.L.; Yu, S.P.; Wei, L. Erythropoietin-induced neurovascular protection, angiogenesis, and cerebral blood flow restoration after focal ischemia in mice. J. Cereb. Blood Flow Metab. 2007, 27, 1043-1054. [CrossRef]

71. Hayashi, T.; Noshita, N.; Sugawara, T.; Chan, P.H. Temporal Profile of Angiogenesis and Expression of Related Genes in the Brain after Ischemia. J. Cereb. Blood Flow Metab. 2003, 23, 166-180. [CrossRef]

72. Yanev, P.; Seevinck, P.R.; Rudrapatna, U.S.; Bouts, M.J.; van der Toorn, A.; Gertz, K.; Kronenberg, G.; Endres, M.; van Tilborg, G.A.; Dijkhuizen, R.M. Magnetic resonance imaging of local and remote vascular remodelling after experimental stroke. J. Cereb. Blood Flow Metab. 2017, 37, 2768-2779. [CrossRef]

73. Zhang, Z.G.; Chopp, M. Neurorestorative therapies for stroke: Underlying mechanisms and translation to the clinic. Lancet Neurol. 2009, 8, 491-500. [CrossRef]

74. Xiong, Y.; Mahmood, A.; Chopp, M. Angiogenesis, neurogenesis and brain recovery of function following injury. Curr. Opin. Investig. Drugs 2010, 11, 298-308.

75. Zhang, Y.; Xiong, Y.; Mahmood, A.; Meng, Y.; Qu, C.; Schallert, T.; Chopp, M. Therapeutic effects of erythropoietin on histological and functional outcomes following traumatic brain injury in rats are independent of hematocrit. Brain Res. 2009, 1294, 153-164. [CrossRef]

76. Chen, J.; Zhang, Z.G.; Li, Y.; Wang, Y.; Wang, L.; Jiang, H.; Zhang, C.; Lü, M.; Katakowski, M.; Feldkamp, C.S.; et al. Statins induce angiogenesis, neurogenesis, and synaptogenesis after stroke. Ann. Neurol. 2003, 53, 743-751. [CrossRef]

77. Chopp, M.; Zhang, Z.G.; Jiang, Q. Neurogenesis, Angiogenesis, and MRI Indices of Functional Recovery From Stroke. Stroke 2007, 38, 827-831. [CrossRef]

78. Chen, J.; Zhang, C.; Jiang, H.; Li, Y.; Zhang, L.; Robin, A.; Katakowski, M.; Lu, M.; Chopp, M. Atorvastatin induction of VEGF and BDNF promotes brain plasticity after stroke in mice. J. Cereb. Blood Flow Metab. 2005, 25, 281-290. [CrossRef]

79. Sonntag, W.E.; Lynch, C.D.; Cooney, P.T.; Hutchins, P.M. Decreases in Cerebral Microvasculature with Age Are Associated with the Decline in Growth Hormone and Insulin-Like Growth Factor 1. Endocrinology 1997, 138, 3515-3520. [CrossRef]

80. Robertson, R.T.; Levine, S.T.; Haynes, S.M.; Gutierrez, P.; Baratta, J.L.; Tan, Z.; Longmuir, K.J. Use of labeled tomato lectin for imaging vasculature structures. Histochem. Cell Biol. 2015, 143, 225-234. [CrossRef]

81. Anrather, J.; Iadecola, C. Inflammation and Stroke: An Overview. Neurotherapeutics 2016, 13, 661-670. [CrossRef]

82. Tuttolomondo, A.; Pecoraro, R.; Casuccio, A.; Di Raimondo, D.; Butta, C.; Clemente, G.; Della Corte, V.; Guggino, G.; Arnao, V.; Maida, C.; et al. Peripheral frequency of CD4+CD28-cells in acute ischemic stroke: Relationship with stroke subtype and severity markers. Medicine 2015, 94, e813. [CrossRef]

83. Tuttolomondo, A.; Pinto, A.; Corrao, S.; Di Raimondo, D.; Fernández, P.; Di Sciacca, R.; Arnao, V.; Licata, G. Immuno-inflammatory and thrombotic/fibrinolytic variables associated with acute ischemic stroke diagnosis. Atherosclerosis 2009, 203, 503-508. [CrossRef] [PubMed]

84. Tuttolomondo, A.; Di Raimondo, D.; Pecoraro, R.; Casuccio, A.; Di Bona, D.; Aiello, A.; Accardi, G.; Arnao, V.; Clemente, G.; Corte, V.D.; et al. HLA and killer cell immunoglobulin-like receptor (KIRs) genotyping in patients with acute ischemic stroke. J. Neuroinflamm. 2019, 16, 88. [CrossRef] [PubMed]

85. Kluge, M.G.; Kracht, L.; Abdolhoseini, M.; Ong, L.K.; Johnson, S.J.; Nilsson, M.; Walker, F.R. Impaired microglia process dynamics post-stroke are specific to sites of secondary neurodegeneration. Glia 2017, 65, 1885-1899. [CrossRef]

86. Sanchez-Bezanilla, S.; Tebay, C.; Nilsson, M.; Walker, F.R.; Ong, L.K. Visual discrimination impairment after experimental stroke is associated with disturbances in the polarization of the astrocytic aquaporin- 4 and increased accumulation of neurotoxic proteins. Exp. Neurol. 2019, 318, 232-243. [CrossRef]

87. Jones, K.; Maltby, S.; Plank, M.; Kluge, M.; Nilsson, M.; Foster, P.; Walker, F. Peripheral immune cells infiltrate into sites of secondary neurodegeneration after ischemic stroke. Brain Behav. Immun. 2018, 67, $299-307$. [CrossRef] 
88. Boehncke, S.; Ackermann, H.; Badenhoop, K.; Sitzer, M. Pituitary Function and IGF-I Levels following Ischemic Stroke. Cerebrovasc. Dis. 2011, 31, 163-169. [CrossRef]

89. Bondanelli, M.; Ambrosio, M.R.; Carli, A.; Bergonzoni, A.; Bertocchi, A.; Zatelli, M.C.; Ceruti, S.; Valle, D.; Basaglia, N.; Degli Uberti, E.C. Predictors of Pituitary Dysfunction in Patients Surviving Ischemic Stroke. J. Clin. Endocrinol. Metab. 2010, 95, 4660-4668. [CrossRef]

90. Lillicrap, T.; Garcia-Esperon, C.; Walker, F.R.; Ong, L.K.; Nilsson, M.; Spratt, N.; Levi, C.R.; Parsons, M.; Isgaard, J.; Bivard, A. Growth Hormone Deficiency Is Frequent After Recent Stroke. Front. Neurol. 2018, 9, 713. [CrossRef]

91. Ong, L.K.; Zhao, Z.; Kluge, M.; Walker, F.R.; Nilsson, M. Chronic stress exposure following photothrombotic stroke is associated with increased levels of Amyloid beta accumulation and altered oligomerisation at sites of thalamic secondary neurodegeneration in mice. J. Cereb. Blood Flow Metab. 2017, 37, 1338-1348. [CrossRef]

92. Zalewska, K.; Pietrogrande, G.; Ong, L.K.; Abdolhoseini, M.; Kluge, M.; Johnson, S.J.; Walker, F.R.; Nilsson, M. Sustained administration of corticosterone at stress-like levels after stroke suppressed glial reactivity at sites of thalamic secondary neurodegeneration. Brain Behav. Immun. 2018, 69, 210-222. [CrossRef]

93. Pietrogrande, G.; Zalewska, K.; Zhao, Z.; Abdolhoseini, M.; Chow, W.Z.; Sanchez-Bezanilla, S.; Ong, L.K.; Johnson, S.J.; Nilsson, M.; Walker, F.R. Low oxygen post conditioning prevents thalamic secondary neuronal loss caused by excitotoxicity after cortical stroke. Sci. Rep. 2019, 9, 4841. [CrossRef]

94. Walser, M.; Hansen, A.; Svensson, P.A.; Jernås, M.; Oscarsson, J.; Isgaard, J.; Åberg, N.D. Peripheral administration of bovine $\mathrm{GH}$ regulates the expression of cerebrocortical beta-globin, GABAB receptor 1, and the Lissencephaly-1 protein (LIS-1) in adult hypophysectomized rats. Growth Horm. IGF Res. 2011, 21, 16-24. [CrossRef]

95. Pietrogrande, G.; Zalewska, K.; Zhao, Z.; Johnson, S.J.; Nilsson, M.; Walker, F.R. Low Oxygen Post Conditioning as an Efficient Non-pharmacological Strategy to Promote Motor Function After Stroke. Transl. Stroke Res. 2019, 10, 402-412. [CrossRef]

96. Kluge, M.G.; Abdolhoseini, M.; Zalewska, K.; Ong, L.K.; Johnson, S.J.; Nilsson, M.; Walker, F.R. Spatiotemporal analysis of impaired microglia process movement at sites of secondary neurodegeneration post-stroke. J. Cereb. Blood Flow Metab. 2018, 39, 2456-2470. [CrossRef]

97. Zhao, Z.; Ong, L.K.; Johnson, S.; Nilsson, M.; Walker, F.R. Chronic stress induced disruption of the peri-infarct neurovascular unit following experimentally induced photothrombotic stroke. J. Cereb. Blood Flow Metab. 2017, 37, 3709-3724. [CrossRef]

98. Sanchez-Bezanilla, S.; Nilsson, M.; Walker, F.R.; Ong, L.K. Can We Use 2,3,5-Triphenyltetrazolium Chloride-Stained Brain Slices for Other Purposes? The Application of Western Blotting. Front. Mol. Neurosci. 2019, 12, 181. [CrossRef]

99. Mullen, R.J.; Buck, C.R.; Smith, A.M. NeuN, a neuronal specific nuclear protein in vertebrates. Development 1992, 116, 201-211.

100. Sanderson, D.; Good, M.; Seeburg, P.; Sprengel, R.; Rawlins, J.; Bannerman, D. The role of the GluR-A (GluR1) AMPA receptor subunit in learning and memory. Prog. Brain Res. 2008, 169, 159-178. [CrossRef]

101. Benner, S.; Kakeyama, M.; Endo, T.; Yoshioka, W.; Tohyama, C. Application of NeuroTrace staining in the fresh frozen brain samples to laser microdissection combined with quantitative RT-PCR analysis. BMC Res. Notes 2015, 8, 252. [CrossRef]

(C) 2020 by the authors. Licensee MDPI, Basel, Switzerland. This article is an open access article distributed under the terms and conditions of the Creative Commons Attribution (CC BY) license (http://creativecommons.org/licenses/by/4.0/). 